\title{
Article \\ Composition, Physicochemical Features, and Covalent Gelling Properties of Ferulated Pectin Extracted from Three Sugar Beet (Beta vulgaris L.) Cultivars Grown under Desertic Conditions
}

\author{
Claudia Lara-Espinoza, Jose A. Sanchez-Villegas, Yolanda Lopez-Franco ${ }^{\mathbb{B}}$, Elizabeth Carvajal-Millan (1), \\ Rosalba Troncoso-Rojas, Tania Carvallo-Ruiz and Agustin Rascon-Chu *(D)
}

Research Center for Food and Development (CIAD), A.C., Carretera Gustavo Enrique Astiazaran Rosas, No. 46, Col. La Victoria, Hermosillo 83304, Sonora, Mexico; claudialaraes@gmail.com (C.L.-E.); asanchez@ciad.mx (J.A.S.-V.); lopezf@ciad.mx (Y.L.-F.); ecarvajal@ciad.mx (E.C.-M.); rtroncoso@ciad.mx (R.T.-R.); tcarvallo@ciad.mx (T.C.-R.)

* Correspondence: arascon@ciad.mx; Tel.: +52-662-289-2400

check for updates

Citation: Lara-Espinoza, C.; Sanchez-Villegas, J.A.; Lopez-Franco, Y.; Carvajal-Millan, E.; Troncoso-Rojas, R.; Carvallo-Ruiz, T.; Rascon-Chu, A. Composition, Physicochemical Features, and Covalent Gelling Properties of Ferulated Pectin Extracted from Three Sugar Beet (Beta vulgaris L.) Cultivars Grown under Desertic Conditions. Agronomy 2021, 11, 40. https://dx.doi.org/10.3390/ agronomy11010040

Received: 12 November 2020 Accepted: 22 December 2020 Published: 28 December 2020

Publisher's Note: MDPI stays neutral with regard to jurisdictional claims in published maps and institutional affiliations.

Copyright: () 2020 by the authors. Licensee MDPI, Basel, Switzerland. This article is an open access article distributed under the terms and conditions of the Creative Commons Attribution (CC BY) license (https: / / creativecommons.org/ licenses/by/4.0/).

\begin{abstract}
Sugar beet is a potential source of pectin, competitive with traditional sources, that has recently acquired great relevance for its interesting covalent gelling and applications in food and biomedical industries. Pectins from three Sugar beet (Beta vulgaris L.) commercial cultivars (Cadet, Coronado large, and SV MEI) were grown under irrigated desertic conditions and the influence of cultivar, on pectin yield, composition, physicochemical and gelling characteristics was investigated. The composition and chemical properties of pectin from the three cultivars were in general, statistically different, especially in the Syngenta Cadet cultivar, presenting higher protein (10.3\%), neutral sugars $(21.6 \%)$, galacturonic acid $(55 \%)$ and ferulic acid $(5.5 \mathrm{mg} / \mathrm{g})$ content, which are important parameters for gel formation. All pectins gelled via oxidative coupling and the main ferulic acid dimers found were 8-5' and 8-O- $4^{\prime}$. Pectin from Cadet cultivar formed gels with higher hardness $(6.65 \mathrm{~N})$ and adhesiveness $(12.2 \mathrm{~N})$ values than the other two varieties. The results indicate that pectin composition is affected by the sugar beet cultivars reported herein, especially in ferulic acid content, which confer the covalent gelling capability. Sugar beet cultivars grown under desert conditions could be a source of gelling ferulated pectins for the food industry, as valuable as those obtained in temperate conditions.
\end{abstract}

Keywords: sugar beet; ferulated pectin; gelling ability; ferulic acid; texture profile analysis

\section{Introduction}

Sugar beet (Beta vulgaris L.) is an herbaceous plant, belonging to the Chenopodaceae family, and traditionally cultivated in temperate countries such as Germany, France, Turkey, Russia, among others, for sugar production [1]. This process generates high percentages of by-products like sugar beet pulp, which contains considerable amounts of polysaccharides such as cellulose, hemicellulose and pectins. The amount of pectin present in the sugar beet pulp can be compared to those obtained from traditional sources like apple pomace or citric peel that are widely used in the food industry as texturizers, emulsifiers, and thickeners [2]. In this regard, pectins are complex polysaccharides from plants primary cell wall and middle lamella. This molecule is formed by a linear chain of 1,4-linked $\alpha$-Dgalacturonic acid (homogalacturonan) and two hairy regions named rhamnogalacturonan I (RGI) and rhamnogalacturonan II (RGII), presenting a high content of neutral sugars in the lateral chains [3]. In addition, sugar beet pectins (SBP) also contain ferulic acid (FA) in their rhamnogalacturonan I region, on position $\mathrm{O}-2$ of arabinans or $\mathrm{O}-6$ of galactans, that allows them to form gels by oxidative coupling [4]. However, weak gels can be formed due to the acetyl groups, lower molecular weight, and side chains [5]. In addition, the presence of FA, high levels of protein and higher content of methyl and acetyl groups confers SBP excellent 
emulsifying properties [6,7]. On the contrary, neutral sugars in the side chains and lower molecular weight have shown prebiotic and anticancer activity [8,9]. Also, the presence of FA gives SBP antioxidant activity [10] and pectin structure has shown immunomodulatory properties [11,12].

Eventually, ferulated pectin gels might also be used as a texturizer for low sugar food products, non-sugar added products or as a fat replacer, since SBP do not require the presence of solutes as sugars nor divalent ions to gel. In fact, its gelling mechanism is carried out by the action of oxidative agents such as enzymes like laccase, triggering the formation of covalent bonds between FA residues in RG I region; a process referred as oxidative coupling [13]. Moreover, the latter mechanism does not exclude other mechanisms and may as well combine with low or high methoxy pectins gelling mechanism, as the methylation degree of HG region structure allows.

Due the abovementioned characteristics, different varieties have been grown in Northwest México Sonoran Desert for bioethanol production. Previously, agronomic evaluation of the three sugar beet cultivars studied in this work was reported for the region, mostly focused on sugar yield and bioethanol production potential. Although the studied varieties have not been previously reported under optimal growing conditions, in terms of temperature, Jimenez-Leon et al. inferred that the cultivation and growth of the studied varieties is feasible under desertic conditions of Northwest Mexico [14]. In this regard, the obtainment of pectin from sugar beet and its physicochemical characteristics has not been fully assessed under the conditions of Northwest México as a function of cultivar. The influence of cultivar on the pectin content and its physicochemical parameters in diverse fruits and vegetables has already been reported [15-17]; following the study, this work hypothesized that pectin content and its physicochemical features are affected by the sugar beet cultivar under the high temperatures of Northwest México. Therefore, the aim of this study is to evaluate the influence of sugar beet cultivar, grown under the Sonoran Desert conditions, on the content of pectin, its physicochemical characteristics, and gelling properties.

\section{Materials and Methods}

\subsection{Plant Material}

Fresh Sugar beet (Beta vulgaris) was grown in the experimental field of the Facultad de Agronomia (Universidad de Sonora) (Coordinates: $29^{\circ} 00^{\prime} 48^{\prime \prime} \mathrm{NL}, 111^{\circ} 08^{\prime} 07^{\prime \prime} \mathrm{WL}$ and 151 masl) under planting and harvesting conditions established by Jimenez-Leon et al. [14]. Three cultivars were used: Cadet, Coronado large (Cor), and SV MEI, obtained by commercial companies. The roots were washed with tap water and soap to remove dirt, and then were cut into $1 \mathrm{~cm}$ thick slices in a slicer machine 1612 (Hobart, Troy, OH, USA) and dried in an oven MP500 (Enviro-Pak Inc., Clackamas, OR, USA) at $50{ }^{\circ} \mathrm{C}$ with a forced airflow of $2.5 \mathrm{~m}^{3} \mathrm{~s}^{-1}$ for $20 \mathrm{~h}$. Finally, the samples were kept frozen at $-40{ }^{\circ} \mathrm{C}$, until use. All the reagents used in this investigation were analytical grade.

\subsection{Pectin Extraction and Purification}

Pectins were extracted from dried sugar beet roots (B. vulgaris), based on the methodology reported by Li et al. [18], with minor variations. Briefly, $150 \mathrm{~g}$ of dried beet were suspended in 1.5 $\mathrm{L}$ of $0.1 \mathrm{M}$ hydrochloric acid $(1: 10 \mathrm{w} / \mathrm{v})$ and $\mathrm{pH}$ was adjusted to 1.5 . The mixture was homogenized, heated on a plate with stirring at $85^{\circ} \mathrm{C}$ for $1 \mathrm{~h}$ and allowed to cool at room temperature. Next, the mixture was filtered through a nylon cloth (pore size $60 \mu \mathrm{m}$ ), centrifuged at $10,000 \times g$ for $20 \mathrm{~min}$ in a centrifuge (Thermo Scientific ${ }^{\mathrm{TM}}$, Waltham, MA, USA). The samples were ethanol precipitated $(2: 1 v / v)$ and dried by the solvent exchange to acetone. Once dry, the samples were grinded in a coffee grinder (Hamilton Beach $^{\circledR}$, Glen Allen, VA, USA) to a fine powder.

The extracted pectins were then purified following the procedure described by Yapo et al. [19] with some modifications. In brief, extracted pectins were dissolved in ultrapure water $(1: 200 w / w)$ for $24 \mathrm{~h}$ with stirring; afterward, centrifuged at $10,000 \times g$ for $20 \mathrm{~min}$ and filtered through $3,1.2,0.8$ and $0.45 \mu \mathrm{m}$ membrane filters, respectively. The 
samples were ethanol precipitated $(2: 1 v / v)$ and dried by the solvent exchange to acetone and stored in the dark at room temperature until use.

\subsection{Pectin Yield}

The pectin yield was determined by the proportion of the weight of the extracted pectin after drying with respect to the original weight of dry sugar beet (g/100 g) [18]. Recovery was calculated as follows,

$$
\text { Pectin yield }(\%)=\frac{m_{0}}{m} \times 100
$$

where $m_{0}(\mathrm{~g})$ : dry pectin weight; $m(\mathrm{~g})$ : dry beet weight.

\subsection{Pectin Characterization}

The galacturonic acid (GalA) content was determined by high performance liquid chromatography (Varian 500, Palo Alto, CA, USA), after hydrolysis of pectin samples with $4 \mathrm{~N}$ trifluoroacetic acid for $2 \mathrm{~h}$ at $120^{\circ} \mathrm{C}$. Samples were suspended in $0.001 \mathrm{~N}$ sulfuric acid and filtered with a $0.45 \mu \mathrm{m}$ membrane prior to injection in a MetaCarb H Plus column (Agilent, Santa Clara, CA, USA; $300 \mathrm{~mm} \times 7.8 \mathrm{~mm}$ ) set at $70{ }^{\circ} \mathrm{C}$ [20].

The neutral sugar composition was performed in agreement with the procedure reported by Wang et al. [21]. Pectin samples were hydrolyzed with $4 \mathrm{M}$ trifluoroacetic acid for $4 \mathrm{~h}$ at $120{ }^{\circ} \mathrm{C}$ and converted to alditol acetate. Derivatized samples were quantified by gas chromatography (Clarus 580, PerkinElmer Inc., Waltham, MA, USA) using a highperformance capillary column Elite 225 (PerkinElmer Inc., $30 \mathrm{~mL} \times 0.32 \mathrm{~mm}$ i.d., $0.15 \mu \mathrm{m}$ film thickness). Samples were filtered in a $0.45 \mu \mathrm{m}$ membrane prior to injection. The total neutral sugar content was calculated as the sum of the total composition of individual neutral sugars.

The FA and dimer content were analyzed by high performance liquid chromatography. Pectin samples were subjected to saponification, acidification, and extraction with diethyl ether. Samples were injected in a chromatograph e2695 (Waters ${ }^{\mathrm{TM}}$, Milford, MA, USA), equipped with a C18 column (Alltech Inc., Lexington, KY, USA; $250 \mathrm{~mm} \times 2.6 \mathrm{~mm}$ ), previously filtered in a $0.45 \mu \mathrm{m}$ membrane [22]. The ash content was determined by the incineration of samples at $600{ }^{\circ} \mathrm{C}$ in a muffle for $4 \mathrm{~h}$ [23]. The soluble protein content was determined according to the Bradford method [24].

The degree of methylation and acetylation were performed following the methodology proposed by Levigne et al. [25], with some modifications. Briefly, $20 \mathrm{mg}$ of pectin were suspended in $250 \mu \mathrm{L}$ of $10 \mathrm{mM}$ copper sulphate $\left(\mathrm{CuSO}_{4}\right)$ and $250 \mu \mathrm{L}$ of $200 \mathrm{mM}$ isopropanol as internal standard, then, $500 \mu \mathrm{L}$ of $1 \mathrm{M} \mathrm{NaOH}$ were added to carry out the saponification (final volume $1 \mathrm{~mL}$ ). The reaction mixture was left at $4{ }^{\circ} \mathrm{C}$ for $1 \mathrm{~h}$. The samples were then centrifuged at $8000 \times g$ for $10 \mathrm{~min}$. Supernatants were neutralized with a syringe equipped with a Maxi-clean IC-H device ( $S^{*}$ pure Pte. Ltd., Singapore), prior to injection. The samples were injected on a liquid chromatography equipment (Varian 500) equipped with a C18 column (Merck ${ }^{\mathrm{TM}}$, Darmstadt, Germany; $250 \mathrm{~mm} \times 4 \mathrm{~mm}$ ) and a guard column LiChroCART (Merck; $4 \mathrm{~mm} \times 4 \mathrm{~mm}$ ), with refractometric detection.

The intrinsic viscosity was inferred from the specific viscosity determined by the flow time of pectin solutions at different concentrations in an Ubbelohde capillary viscometer AVS $400^{\circledR}$ (Schott Geräte, Hofheim, Germany) at $25^{\circ} \mathrm{C}$. The pectin solution was dissolved in $0.09 \mathrm{M} \mathrm{NaCl}$ and filtered in a $0.45 \mu \mathrm{m}$ membrane before the measurements. Intrinsic viscosity $([\eta])$ was determined from the relative viscosity of pectin solutions by extrapolation of Huggins and Kraemer curves to "zero" concentration [26].

The molecular weight of pectin samples of the three cultivars of sugar beet was determined by high-performance size exclusion chromatography. One milliliter of a pectin solution $(0.1 \% w / v)$ was dissolved in $0.1 \mathrm{M}$ lithium nitrate. The samples were filtered with a $0.45 \mu \mathrm{m}$ membrane and injected in a high-performance liquid chromatography equipment e2695 (Waters ${ }^{\mathrm{TM}}$ ), at $38^{\circ} \mathrm{C}$ equipped with an Ultra hydrogel 1000 column 
(Waters ${ }^{\mathrm{TM}} ; 300 \mathrm{~mm} \times 7.8 \mathrm{~mm}$ ), using pullulan as standard with molecular weight within the range of 50 to $800 \mathrm{kDa}$ [27].

Attenuated total reflection Fourier-transform infrared (ATF-FTIR), was used to analyze the samples, using a spectrometer (NICOLET IS-50, ThermoScientific ${ }^{\mathrm{TM}}$, Waltham, MA, USA) in a wavenumber range of $400-4000 \mathrm{~cm}^{-1}$. The conditions for the sample were completely dry powder samples and absorbance graphs were obtained against the frequency expressed as wavenumber [28].

\subsection{Ferulated Pectin Gel Casting}

Pectin solutions at $2 \%(w / v)$ were prepared in $0.1 \mathrm{M}$ sodium acetate buffer $\mathrm{pH} 5.5$ and set on stirring overnight for dissolution. The buffer was previously filtered through $0.45 \mu \mathrm{m}$ (Whatman ${ }^{\circledR}$, Maidstone, UK) to prevent microbial contamination. Laccase from Trametes versicolor $(13.6 \mathrm{U} / \mathrm{mg})$ was used as cross-linking agent at $1.675 \mathrm{nkat}$ laccase $/ \mathrm{mg}$ pectin. Gels settled at $25^{\circ} \mathrm{C}$ for $2 \mathrm{~h}$.

\subsection{Texture Profile Analysis}

The texture profile analysis (TPA) of ferulated pectin gels at $2 \%(w / v)$, freshly made $\left(2 \mathrm{~h} @ 25^{\circ} \mathrm{C}\right.$ ), was performed in glass beakers of $50 \mathrm{~mL}$ with $55 \mathrm{~mm}$ of height and $35 \mathrm{~mm}$ of internal diameter, using a TA.XT2 Texture Analyzer (Texture Analyzer Stable Micro Systems, Surrey, UK). The gels were deformed by compression at a constant speed of $1.0 \mathrm{~mm} / \mathrm{s}$ to $4 \mathrm{~mm}$ from the gel surface using a cylindrical plunger (diameter $25.4 \mathrm{~mm}$ ). The parameters evaluated were hardness, fracturability, adhesiveness, springiness, cohesiveness, gumminess, and chewiness [29].

\subsection{Statistical Analysis}

All measurements were performed by triplicate and expressed as mean values with standard deviation. To determine significant differences between the three cultivars, a one-way analysis of variance (ANOVA) was performed and the mean values were then compared by Tuckey-Kramer multiple test $(* p \leq 0.05)$, using NCSS 12 software.

\section{Results and Discussion}

\subsection{Pectin Yield}

The recovery percentages of pectin were 5.0, 5.8 and $6.3 \%$, for the cultivars Cadet, Cor, and SV MEI, respectively (Table 1). No significant differences $(p>0.05)$ were found between the three cultivars. The pectin yield obtained in this investigation was lower than previously reported by Guo et al. [30], who found a yield of $9.6 \%$ for pectins in sugar beet pulp, not fresh samples. Several authors report that the extraction conditions have important effects on the quantity, as well as the quality of the extracted pectins. Among the main affecting parameters are temperature, $\mathrm{pH}$, extraction time and the nature of the acid [31], being probably, $\mathrm{pH}$ the main factor influencing yield, rather than cultivar.

Although, time, $\mathrm{pH}$ and temperature were comparable to those reported by Guo et al. [30], the extraction solvent differs from these authors, which probably explains the lower yields in this investigation. Li et al. [18] established that an adequate solvent in the extraction process could effectively hydrolyze the insoluble pectin to soluble. Also, the start material impact directly on the pectin quantity extracted, being a parameter of great interest for future applications.

\subsection{Pectin Composition}

The content of pectin in GalA, neutral sugars and FA was assessed for all three cultivars. The GalA percentage was 62.7, 55.0 and $47.0 \%$ for SV MEI, Cadet and Cor, respectively. The results are shown in Table 1 below. These values were higher than those obtained by Chen et al. [7], who reported a percentage of $\approx 44$ of GalA in sugar beet pulp under similar extraction conditions. This difference can probably be due to the starting materials as the present study uses plant material as harvested, for pectin extraction. Within 
the samples, the content of GalA was higher for the SV MEI and Cadet cultivars, though statistically similar.

Table 1. Yield and physicochemical composition of pectins extracted from three cultivars of sugar beet roots .

\begin{tabular}{|c|c|c|c|}
\hline & Cadet & SV MEI & Cor \\
\hline Yield (\%) & $5.0 \pm 0.6^{\mathrm{a}}$ & $6.3 \pm 0.8^{a}$ & $5.8 \pm 0.7^{\mathrm{a}}$ \\
\hline Galacturonic acid (\%) & $55.0 \pm 3^{\mathrm{ab}}$ & $62.7 \pm 0.4^{b}$ & $47.0 \pm 4^{\mathrm{a}}$ \\
\hline \multicolumn{4}{|l|}{ Neutral sugars: } \\
\hline Rhamnose (\%) & $6.3 \pm 0.5^{b}$ & $4.4 \pm 0.3^{\mathrm{a}}$ & $3.5 \pm 0.3^{a}$ \\
\hline Fucose $(\%)$ & $1.2 \pm 0.1^{b}$ & $0.63 \pm 0.05^{\mathrm{a}}$ & $0.74 \pm 0.07^{\mathrm{a}}$ \\
\hline Arabinose $(\%)$ & $3.3 \pm 0.4^{\mathrm{a}}$ & $6.2 \pm 0.6^{b}$ & $7.1 \pm 0.7^{b}$ \\
\hline Xylose (\%) & $1.4 \pm 0.2^{\mathrm{a}}$ & $1.1 \pm 0.1^{\mathrm{a}}$ & $1.2 \pm 0.1^{\mathrm{a}}$ \\
\hline Mannose (\%) & $1.3 \pm 0.2^{b}$ & $1.0 \pm 0.1^{\mathrm{a}}$ & $1.0 \pm 0.1^{\mathrm{a}}$ \\
\hline Galactose(\%) & $7.1 \pm 0.5^{b}$ & $5.1 \pm 0.7^{\mathrm{a}}$ & $6.3 \pm 0.6^{\mathrm{ab}}$ \\
\hline Glucose (\%) & $1.00 \pm 0.01^{b}$ & $1.18 \pm 0.05^{\mathrm{c}}$ & $0.62 \pm 0.05^{\mathrm{a}}$ \\
\hline Total neutral sugars (\%) & $21.6 \pm 0.9^{a}$ & $19.6 \pm 1.0^{\mathrm{a}}$ & $20.5 \pm 1.0^{\mathrm{a}}$ \\
\hline $\mathrm{FA}(\mathrm{mg} / \mathrm{g})$ & $5.5 \pm 0.1^{\mathrm{c}}$ & $3.5 \pm 0.1^{\mathrm{a}}$ & $4.7 \pm 0.2^{b}$ \\
\hline Feruloyl dimers (mg/g) & $0.26 \pm 0.03^{b}$ & $0.16 \pm 0.02^{\mathrm{a}}$ & $0.25 \pm 0.04^{b}$ \\
\hline Ash $(\%)$ & $2.13 \pm 0.06^{b}$ & $2.2 \pm 0.2^{b}$ & $1.8 \pm 0.1^{\mathrm{a}}$ \\
\hline Protein $(\%)$ & $10.3 \pm 0.5^{\mathrm{b}}$ & $8.7 \pm 0.7^{\mathrm{a}}$ & $8.6 \pm 0.8^{a}$ \\
\hline DM (\%) & $57.4 \pm 4.1^{\mathrm{b}}$ & $50.8 \pm 1.1^{\mathrm{a}}$ & $55.5 \pm 2.3^{a b}$ \\
\hline DA (\%) & $26.1 \pm 2.4^{b}$ & $19.64 \pm 0.81^{\mathrm{a}}$ & $23.1 \pm 1.6^{b}$ \\
\hline$[\eta](\mathrm{mL} / \mathrm{g})$ & $225 \pm 14^{\mathrm{a}}$ & $255 \pm 18^{a}$ & $202 \pm 4^{\mathrm{a}}$ \\
\hline $\mathrm{Mw} *(\mathrm{KDa})$ & 616 & 665 & 642 \\
\hline
\end{tabular}

DM, Degree of methylation; DA, Degree of acetylation; [ $]$, intrinsic viscosity; Mw, average molecular weight. \# Values are presented as means \pm standard deviations $(n=3)$; Mean values in the same row with different letters are significantly different $(* p \leq 0.05) .{ }^{*}$ Single estimation.

Homogalacturonans (GalA) represents the main component in the pectin structure, and it has been demonstrated that the presence of GalA confers pectin immunomodulatory activity. In general, the activity will depend on the number of GalA residues content and its structure, specifically, the degree of methylation, branching and molecular weight of the fraction [32]. So, pectin polysaccharides hydrolysates can activate the function of macrophages, promote the production of cytokines and phagocytic activity, thus, regulate the immune system in multiple levels $[33,34]$. In theory, pectins obtained here are likely candidates for potential immunomodulatory effect when ingested and fermented by colon microbiota, or previously hydrolyzed by enzymatic, chemical, or physical means. Research on these processes and products obtained are of great interest for human health applications.

The total neutral sugar percentage ranged from 19.6 up to $21.6 \%$, according to beet cultivar. These results agree with previous reports, where the total neutral sugar percentage was around $22.0 \%$ for SBP [35]. The total neutral sugar percentage was statistically similar for the three cultivars. The main neutral sugars present in beet pectins were rhamnose (3.5-6.3\%), galactose (5.1-7.1\%) and arabinose (3.3-7.1\%), suggesting the presence of galactans and arabinogalactans in the branched regions. Galactose and arabinose were the main neutral sugars in the lateral chains of the structure of pectin; followed by other neutral sugars, such as, glucose, mannose, and xylose in lower amounts (Table 1). It has been reported that galactose and arabinose are the main neutral sugars in the lateral chains of the RGI region [36], which suggest that the three pectins obtained in this work present RGI regions high in Galactose, Rhamnose and arabinose.

The relevance of these structural aspects is that neutral sugars, mainly arabinans or arabino/galacto-oligosaccharides, have been shown prebiotic to humans [8,37]. This feature has been shown of interest for biomedical applications. Gullón et al. [38] established that the prebiotic effect of ferulated pectins depends on the physical and chemical 
characteristics. Also, the pectin source has an important impact on the prebiotic activity due to its determined chemical structure [39]. Our chemical evidence suggests that the pectins obtained may be interesting for prebiotic effect ulterior research.

Furthermore, modified sugar beet pectin has shown anticancer and antiproliferative activity [9]. The mechanism of action of pectin is still under discussion, but apparently, structural features and forms of pectin such as $\mathrm{pH}$ modified pectin, RGI rich pectin, heat modified pectin and dietary fiber play an important role in performing these properties [40]. In this context, the RGI region, specifically shorter, low branched, galactose rich fractions in pectin have shown to have the ability to interact with galectin-3, a protein that is strongly related with metastasis in cancer, acting as a binder for the galectin-3 receptor site [41,42]. In this regard, the percentages of neutral sugars such as galactose (galactans), arabinose (arabinans), or arabinogalactans obtained from SBP of the three cultivars can be suitable to further studies on their prebiotic and anticancer activity, when similar features have been related to such activities on human health.

The FA content for pectin from each cultivar is shown in Table 1. This compound was significantly higher in the Cadet cultivar with a concentration of $5.5 \mathrm{mg} / \mathrm{g}$ of pectin, which represents $0.55 \%$ of FA in this study. Nevertheless, this result was lower than values reported by other authors for pectins extracted from sugar beet $(1.12 \% ; 1.2 \%)[7,43]$. The importance of FA content not only resides in its antioxidant activity but also for its role on covalent gelling mechanism by oxidative coupling. It is well-established that FA is linked to pectic polysaccharides, and it is an important component of the cell wall [44]; however, the reason for lower content of FA in this research are still unclear. Evidently, the samples were expected to show more FA as they were not subjected to any industrial processing; nevertheless, several factors as cultivar and extraction conditions can lower the final content for this compound. In terms of extraction conditions, the method used in this investigation differs lightly from those reported by the cited studies. Apparently, the more aggressive extraction conditions used in this investigation caused the release of neutral sugars like galactose or arabinose were FA is bonded to. Also, a larger molecular size may as well have played a role in the FA proportion reported in the present work. On the other hand, oven drying may also have diminished FA content.

In addition, some FA may be present in the form of dimers. In this regard, the total feruloyl dimers are shown in Table 1 and were statistically higher $(p<0.05)$ for the Cor and Cadet cultivars, while SV MEI had the lower content. The values ranged between 0.16 to $0.26 \mathrm{mg} / \mathrm{g}$ of pectin. The main dimers of FA determined in our samples were $8-5^{\prime}, 8-5^{\prime}$ benzo, $8-O-4^{\prime}$ and $5-5^{\prime}$ dimers, where dimers $8-5^{\prime}$ and $8-O-4^{\prime}$ were the major dimers found. The latter agrees with previous reports where $8-5^{\prime}$ and $8-O-4^{\prime}$ are the main dimers found in sugar beet pectins and related to intercatenary binding. [45].

The ash content for three cultivars of SBP ranged between 1.8-2.2\%. As shown in Table 1, a significant difference was found in the Cor cultivar. The results obtained in this investigation were lower than the reported on SBP, submitted to a similar extraction process, obtaining an ash value of 3.8\% [46]. The marked difference between the reported study and this work may lie in the purification process carried out in this investigation to reduce the non-pectin compounds like ash, oxalate salts, protein, and neutral sugars, which can interfere with the gelling process. Also, as food additive pectin must satisfy certain standards in terms of purity and quality. In relation to food safety, for example, the oral intake of insoluble oxalate salts can represent a risk for human health [35,47].

The protein content ranged between $8.6-10.3 \%$ being statistically higher for the Cadet cultivar. The results obtained in this investigation were almost two-fold higher than the reported in other investigations with percentages between 4 and 5\% [7,48]. Some authors suggest that the extraction conditions (weak or strong acids) could significantly influence the covalent linkages between pectin and protein [18]. Therefore, in this investigation, hydrochloric acid was used as an extracting agent and is considered a strong acid in contrast to citric acid. Also, the protein content is strongly affected by the increment 
of temperature, extraction time and decrease of $\mathrm{pH}$ value, so aggressive conditions can contribute to the hydrolysis of protein [49].

The high protein content in these sugar beet pectins confers an advantage as is widely reported that protein confers excellent emulsifying properties $[48,50]$. This property renders quality pectin with wide potential uses for the food industry as an additive for desserts, fat incorporation, and texture development. Also, SBP was shown to be a promising emulsifying material for the microencapsulation of lipophilic food ingredients like orange and rapeseed oils [51], as well as fish oil [52].

On the other hand, the degree of methylation (DM) of the three cultivars of SBP ranged from 50.8 to $57.4 \%$, showing significant differences $(p<0.05)$ between beet cultivar (Table 1). The data obtained by chromatography for the degree of esterification presented in Table 1 is in concordance to the analysis by Fourier Transform infrared spectroscopy (FT-IR) observing a greater absorbance at wavelength of $1750 \mathrm{~cm}^{-1}$ than at $1650 \mathrm{~cm}^{-1}$, which correlates to high methoxyl pectins structural features. Several authors reported degrees of esterification for high methoxyl pectins with values between 50 and $60 \%$ [53], which agrees with the reported values in the present work. High methyl esterified pectins can also act as a food emulsifier or texturizing in food products, specifically for its proportion of ester groups [6]. Although the content of protein and FA make the main contribution to the emulsifying capacity of SBP [7].

In contrast, the degree of acetylation (DA) ranged from 19.6 to $26.1 \%$, being statistically higher for the Cadet cultivar (Table 1). The degrees of acetylation obtained in this investigation agree with previous publications reporting a percentage of $23.8 \%$ [30]. Sugar beet pectins have higher degrees of acetylation compared to pectins obtained from traditional sources. The presence of acetyl groups in the structure of pectin confers an excellent emulsifying property, also, as mentioned above, for the presence of protein complexes and FA [7].

The intrinsic viscosity was 255, 225 and $202 \mathrm{~mL} / \mathrm{g}$ for SV MEI, Cadet and Cor, respectively, being statistically similar between the three cultivars. Huang et al. [54] obtained similar results with an intrinsic viscosity of 170.5 to $218.3 \mathrm{~mL} / \mathrm{g}$ in pectin extracted from sugar beet pulp, under similar extraction conditions. Levigne et al. [25] assumed that parameters like $\mathrm{pH}$, temperature and $\mathrm{pH}$-temperature interaction have an important effect over the viscosity of molecules. In addition, Huang et al. [54] found that particle size influences intrinsic viscosity of pectin, as well.

The average molecular weights estimated for main pectins were 616,642 and $665 \mathrm{kDa}$ for Cadet, Cor and SV MEI, respectively (Table 1). These results were higher than reported for SBP by Karnik et al. [55] with molecular weights of 399 to $544 \mathrm{kDa}$, but lower than those reported in other investigations $(890 \mathrm{KDa})$ [56]. The small shoulder above $800 \mathrm{kDa}$ is a secondary smaller fraction with superior molecular weights, but the most abundant chains of pectin range from 616 up to $665 \mathrm{kDa}$. In this work, no difference was appreciated among the beet cultivars. The elution profiles of pectin extracted from three cultivars of sugar beet roots are shown in Figure 1. These patterns exhibited a wide molecular weight distribution, which is characteristic of sugar beet pectins, being heterogeneous between the three varieties. Polydispersity is a common feature for this method of extraction.

Intrinsic viscosity and average molecular weight are parameters of great importance in terms of technological applications and gelling capacity of pectin. A higher molecular mass and viscosity allows intermolecular interactions between polysaccharide chains, facilitating the formation of the three-dimensional network. Accordingly, pectin with low molecular weight form weak gels but present several benefits to human health, so, the functionality of pectin depends on its structural and chemical parameters. Also, diverse authors stablished that these physical features can be directly affected by the plant source and extraction conditions $[57,58]$. 


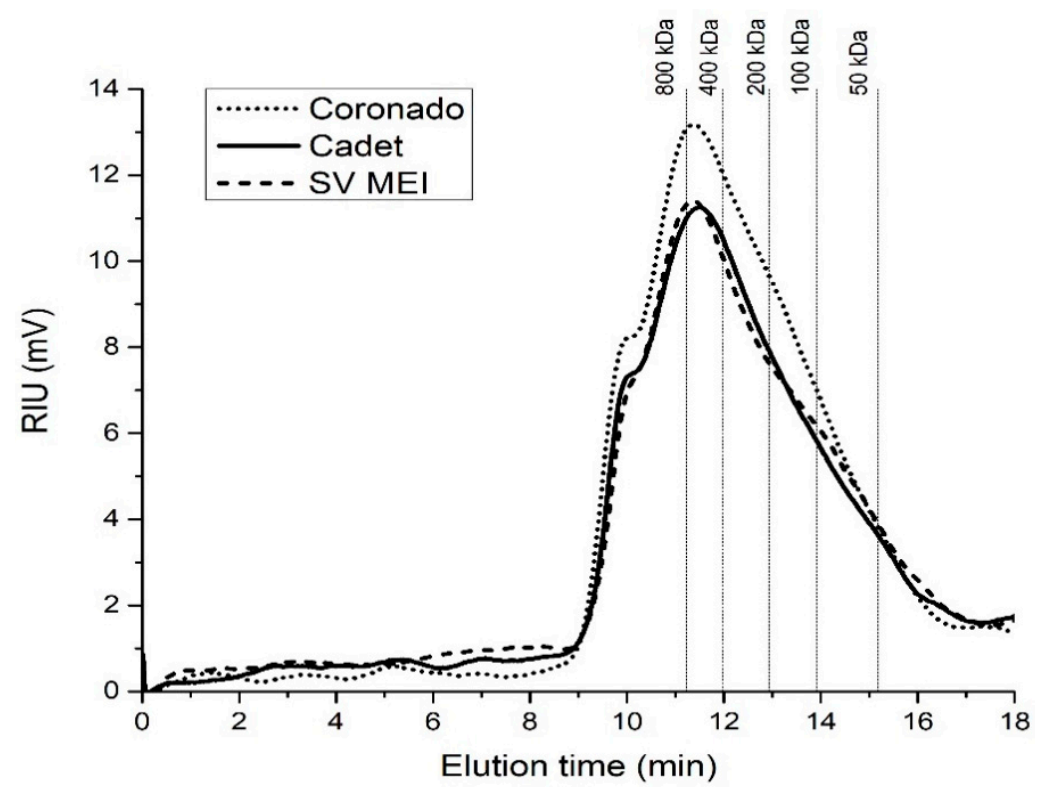

Figure 1. Elution profile of pectins extracted from three cultivars of sugar beet roots. Pullulans were used as standard in the range of 50-800 KDa. Results are result of duplicates.

Another aspect of SBP characterization is exploration of main groups present in its structure by infrared spectroscopy. For molecular identity of pectins, infrared spectra from three cultivars of sugar beet pectins were obtained. Figure 2 shows the FTIR spectra profiles. The wavelength range of $950-1200 \mathrm{~cm}^{-1}$ corresponds to the so-called "fingerprint" region of carbohydrates and is specific for each polysaccharide. In this spectral area, the wavelength numbers of 964, 1020, 1095 and $1130 \mathrm{~cm}^{-1}$ show the characteristic bands corresponding to the profile of polygalacturonic acid, the main component of pectins, represented by the $\mathrm{C}-\mathrm{OH}$ stretching vibrations of side groups and a $\mathrm{C}-\mathrm{O}-\mathrm{C}$ stretching corresponding to the glycosidic bond. In the $1015 \mathrm{~cm}^{-1}$ wavelength are shown the $\mathrm{C}-\mathrm{O}$ stretching bonds associated with sugars [55].

At the wavenumber of $1518 \mathrm{~cm}^{-1}$ approximately, an absorption band can be observed in the SBP profiles, which corresponds to the $\mathrm{C}=\mathrm{C}$ stretching. However inconclusive, the pattern is in accordance to the presence of feruloyl groups and/or protein attached to the pectin structure [59]. The absorption band at $1650 \mathrm{~cm}^{-1}$ in the pectins spectra was due to the $\mathrm{COO}-$ stretching that may correspond to the free carboxyl groups and the $\mathrm{OH}$ bending vibration of water; in the wavenumber of $1750 \mathrm{~cm}^{-1}$ corresponds to the $\mathrm{C}=\mathrm{O}$ stretching corresponding to the esterified carboxyl groups [60]. The three cultivars studied presented higher intensity in the band corresponding to the esterified carboxyl groups. Therefore, the comparison of the intensities of the 1650 and $1750 \mathrm{~cm}^{-1}$ absorption bands strongly suggest the high degree of esterification of pectins, as previously stated in the above sections.

The studied pectins also presented an absorption band in the region of 2800 to $3000 \mathrm{~cm}^{-1}$ corresponding to $\mathrm{C}-\mathrm{H}$ bonds, mostly from the methyl ester groups present. The absorbance bands from 3200 to $3600 \mathrm{~cm}^{-1}$ correspond to $\mathrm{OH}$ groups of the carbohydrate backbone, in the case of our pectin samples, this absorption was attributed to inter and intramolecular hydrogen bonding of the galacturonic acid backbone [15]. The absorption bands shown are in agreement with the known bands for commercial pectin, and several reports for SBP molecular identity [28,35]. 


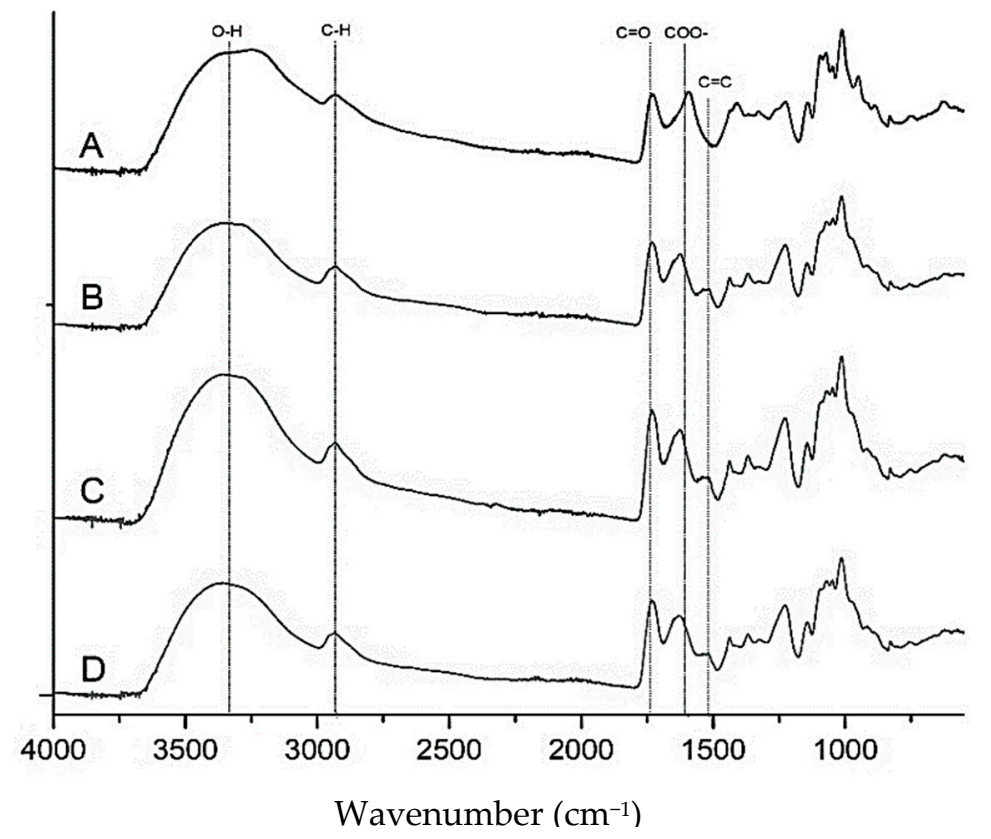

Figure 2. FTIR spectra of pectin from three cultivars of sugar beet. (A) Commercial citric pectin, (B) Coronado large, (C) Cadet, (D) SV MEI.

\subsection{Ferulated Pectin Gelling Capability and Texture Profile Analysis}

Several authors have extensively reported that sugar beet pectins have poor gelling properties under current conditions (presence of co solutes or divalent ions), the latter due to its high content of acetyl groups and the number of side chains. Nevertheless, the presence of FA in its structure allows the formation of gels by oxidative coupling through the establishment of interchain dimers of FA $[6,49,61]$. Although the FA percentage $(0.55 \%)$ obtained in SBP structure was lower than previously reported in other investigations, with values within1.12; and 1.2\%; still it was enough to allow the formation of gels. This process was achieved efficiently using laccase enzyme as a crosslinking agent. Factors like polysaccharide concentration, gelling time and enzyme concentration directly affects the gelling capability of pectins [61]. The physical properties of the gels obtained for pectins from three sugar beet cultivars were evaluated through a texture profile as TPA. The results obtained are shown in Table 2.

The parameters of hardness, adhesiveness, gumminess, and chewiness were statistically higher for the Cadet cultivar $(6.65 \pm 0.42,-12.2 \pm 1.4,1.91 \pm 0.23,1.76 \pm 0.23$, respectively); while cohesiveness was statistically higher for SV MEI cultivar $(0.58 \pm 0.05)$. No significant difference was found for fracturability in the three cultivars. The springiness was significantly smaller for the Cadet cultivar $(0.92 \pm 0.01)$. Pectin from Cadet cultivar presented higher texture values, mainly in hardness and adhesiveness.

Pectin from this cultivar presented the highest content of FA and protein content (Table 1), which can explain the higher hardness value, since the number of cross-links between FA residues present in the polysaccharide chains influences the gelling capacity; thus, the higher the number of cross-links, the higher the gel hardness. Also, the relative arabinose/galacturonic acid ratio was lower for the Cadet cultivar (data not shown) as compared to the other two cultivars, which suggest a less branched structure that could allow the enzyme access to FA residues. Nevertheless, further research is needed to attain more conclusive results. 
Table 2. Texture profile analysis for pectin hydrogels from three sugar beet cultivars.

\begin{tabular}{cccccccc}
\hline Cultivar & $\begin{array}{c}\text { Hardness } \\
(\mathbf{N})\end{array}$ & $\begin{array}{c}\text { Fracturability } \\
(\mathbf{N})\end{array}$ & $\begin{array}{c}\text { Adhesiveness } \\
\mathbf{( N / s )}\end{array}$ & $\begin{array}{c}\text { Springiness } \\
(\mathbf{m m})\end{array}$ & Cohesiveness & $\begin{array}{c}\text { Gumminess } \\
(\mathbf{N})\end{array}$ & $\begin{array}{c}\text { Chewiness } \\
(\mathbf{N})\end{array}$ \\
\hline Cadet & $6.65 \pm 0.42^{\mathrm{a}}$ & $2.03 \pm 0.27^{\mathrm{a}}$ & $-12.2 \pm 1.4^{\mathrm{a}}$ & $0.92 \pm 0.01^{\mathrm{b}}$ & $0.29 \pm 0.02^{\mathrm{b}}$ & $1.91 \pm 0.23^{\mathrm{a}}$ & $1.76 \pm 0.23^{\mathrm{a}}$ \\
SV MEI & $1.12 \pm 0.09^{\mathrm{b}}$ & $1.55 \pm 0.81^{\mathrm{a}}$ & $-7.21 \pm 0.76^{\mathrm{b}}$ & $0.95 \pm 0.01^{\mathrm{a}}$ & $0.58 \pm 0.05^{\mathrm{a}}$ & $0.68 \pm 0.18^{\mathrm{b}}$ & $0.64 \pm 0.16^{\mathrm{b}}$ \\
Cor & $1.04 \pm 0.14^{\mathrm{b}}$ & $2.26 \pm 0.17^{\mathrm{a}}$ & $-5.47 \pm 0.28^{\mathrm{b}}$ & $0.95 \pm 0.006^{\mathrm{a}}$ & $0.27 \pm 0.03^{\mathrm{b}}$ & $0.47 \pm 0.11^{\mathrm{b}}$ & $0.57 \pm 0.12^{\mathrm{b}}$ \\
\hline
\end{tabular}

Values are presented as means \pm standard deviation $(n=3)$; Mean values in the same column with different letters are significantly different $(p \leq 0.05)$.

The information available on texture profile analysis of SBP gels is still limited, and most investigations are focused on the use of sugar beet fiber (SBF) for food applications in products like frankfurters [62], Turkish-type salami [63], cook meat emulsions [64], among others. In this context, Berrin et al. [64] reported texture values in terms of springiness of $0.943 \mathrm{~mm}$, a gumminess of $0.505 \mathrm{~N}$ and a cohesiveness of 0.510 in cook meat emulsions added with SBF (2\%), which agreed to those found for SBP gels from the three cultivars at the same concentration. These authors also inferred that as the SBF concentration was increased, the textural properties were improved.

In relation to the study of sugar beet pectin gels, Norsker et al. [65] evaluated the gelation of sugar beet pectin using two types of laccase as crosslinking agents and reported values of hardness of 11.2 and $10.0 \mathrm{~N}$ and a chewiness of 3.7 and $1.9 \mathrm{~N} / \mathrm{s}$ being both higher than the obtained in this investigation. Nevertheless, these authors also evaluated the gelling capacity of pectin in food products as semi-skimmed milk, obtaining a firm gel with hardness values of $7 \mathrm{~N}$, which is consistent with the obtained in pectin gels, specifically from Cadet cultivar $(6.65 \mathrm{~N})$.

On the other hand, Kuuva et al. [13] evaluated two types of sugar beet pectin from different regions, inferring that pectin with a higher content of acetyl and methyl groups was less effective to gel. Also, these authors established that the texture properties, in terms of hardness of gel, can be increased by the addition of calcium $\left(\mathrm{Ca}^{2+}\right)$ ions along with the enzyme (laccase) at high enzyme activities, to establish both covalent and ionic bonds. $\mathrm{pH}$ was also a parameter that directly affected the hardness properties of pectin gels with or without $\mathrm{Ca}^{2+}$ addition.

The TPA results obtained in this investigation indicated that pectins evaluated, particularly pectin from Cadet cultivar, showed apparently adequate physical characteristics to be potentially used as a gelling or texturizing agent for food industry, although future investigations on food products added with sugar beet pectins acting as gelling/texturizing agents should be conducted. Additionally, nowadays, the search and demand for safe and healthy food additives have been increasing. Sugar beet pectin has acquired great relevance as a food additive since ferulated pectins do not require co solutes, such as sugar or divalent ions, such as calcium to gel and this represents an advantage over traditional pectins since they gel by the action of enzymes through covalent bonds, providing stability to changes in $\mathrm{pH}$ and temperature. Said features have been proved valuable for food industry developing low sugar foods or without added sugar, as well as a fat substitute.

Water is a scarce and high value commodity in the desert and the efficient use of water for these cultivars reported by Jimenez-León et al. [14], supports the diversification of crop production and commercial transformation of produce in desertic Northwest Mexico. Table sugar, bioethanol and now pectins could be products of interest for the region agricultural landscape.

\section{Conclusions}

The results obtained in this investigation support that the composition and physicochemical features of pectin extracted from sugar beet were affected lightly by the cultivars tested. This study provides an overview on varieties suitable for cultivation under desert conditions. The sugar beet cultivars studied contained pectins with properties comparable to those grown in temperate conditions and commercially available, giving a value-addition 
for future applications in food and biomedical/pharmaceutical industries. The mechanical properties and structural characteristics, mainly, the presence of ferulic acid and rich fractions of galactose and/or arabinose in the RGI regions suggest that prebiotic, and antioxidant activity could be worth considering for future research. Storage and extraction conditions are also an opportunity to further knowledge on the topic.

Author Contributions: C.L.-E. and A.R.-C. designed and performed the manuscript; C.L.-E. developed the experimental work; Y.L.-F., E.C.-M. and J.A.S.-V. reviewed and edited the manuscript; R.T.-R. reviewed the manuscript and facilitated material to the development of the investigation; T.C.-R. reviewed and supplied the equipment to perform experimental work. All authors have read and agreed to the published version of the manuscript.

Funding: This research received no external funding.

Data Availability Statement: Publicly available datasets were analyzed in this study. This data can be found here: https:/ / ciad.repositorioinstitucional.mx/jspui/.

Acknowledgments: The authors would like to thank CONACYT for grant number CB-2015-01254297 to A. Rascón-Chu. Also, authors thank Jorge Marquez-Escalante for the technical support during the experimental development.

Conflicts of Interest: The authors declare no conflict of interest.

\section{References}

1. Smulders, M.J.; Esselink, G.D.; Everaert, I.; De Riek, J.; Vosman, B. Characterisation of Sugar Beet (Beta vulgaris L. ssp. vulgaris) Varieties Using Microsatellite Markers. BMC Genet. 2010, 11, 1-11. [CrossRef]

2. Fissore, E.N.; Ponce, N.M.A.; Matkovic, L.; Stortz, C.A.; Rojas, A.M.; Gerschenson, L.N. Isolation of Pectin-Enriched Products from Red Beet (Beta vulgaris L. var. conditiva) Wastes: Composition and Functional Properties. Food Sci. Technol. Int. 2011, 17, 517-527. [CrossRef] [PubMed]

3. Wefers, D.; Tyl, C.E.; Bunzel, M. Novel Arabinan and Galactan Oligosaccharides from Dicotyledonous Plants. Front. Chem. 2014, 2, 1-9. [CrossRef] [PubMed]

4. Ralet, M.C.; André-Leroux, G.; Quéméner, B.; Thibault, J.F. Sugar Beet (Beta vulgaris) Pectins Are Covalently Cross-Linked through Diferulic Bridges in the Cell Wall. Phytochemistry 2005, 66, 2800-2814. [CrossRef] [PubMed]

5. Peng, X.; Mu, T.; Zhang, M.; Sun, H.; Chen, J.; Yu, M. Effects of PH and High Hydrostatic Pressure on the Structural and Rheological Properties of Sugar Beet Pectin. Food Hydrocoll. 2016, 60, 161-169. [CrossRef]

6. Williams, P.A.; Mazoyer, J.; Senan, C.; Viebke, C.; Boulenguer, P.; Sayers, C. Elucidation of the Emulsification Properties of Sugar Beet Pectin. J. Agric. Food Chem. 2005, 53, 3592-3597. [CrossRef]

7. Chen, H.M.; Fu, X.; Luo, Z.G. Effect of Molecular Structure on Emulsifying Properties of Sugar Beet Pulp Pectin. Food Hydrocoll. 2016, 54, 99-106. [CrossRef]

8. Prandi, B.; Baldassarre, S.; Babbar, N.; Bancalari, E.; Vandezande, P.; Hermans, D.; Bruggeman, G.; Gatti, M.; Elst, K.; Sforza, S. Pectin Oligosaccharides from Sugar Beet Pulp: Molecular Characterization and Potential Prebiotic Activity. Food Funct. 2018, 9 , 1557-1569. [CrossRef]

9. Maxwell, E.G.; Colquhoun, I.J.; Chau, H.K.; Hotchkiss, A.T.; Waldron, K.W.; Morris, V.J.; Belshaw, N.J. Modified Sugar Beet Pectin Induces Apoptosis of Colon Cancer Cells via an Interaction with the Neutral Sugar Side-Chains. Carbohydr. Polym. 2016, 136, 923-929. [CrossRef]

10. Aarabi, A.; Honarvar, M.; Mizani, M.; Faghihian, H. Determination of Total Phenolic Compounds, Antioxidant Activity and Ferulic Acid in Extracts of Sugar Beet Pulp. J. Biol. Chem. 2015, 43, 251-257. [CrossRef]

11. Rösch, C.; Taverne, N.; Venema, K.; Gruppen, H.; Wells, J.M.; Schols, H.A. Effects of in Vitro Fermentation of Barley $\beta-$ Glucan and Sugar Beet Pectin Using Human Faecal Inocula on Cytokine Expression by Dendritic Cells 3. Mol. Nutr. Food Res. 2016, 61, 1-23. [CrossRef]

12. Meijerink, M.; Rösch, C.; Taverne, N.; Venema, K. Structure Dependent-Immunomodulation by Sugar Beet Arabinans via a SYK Tyrosine Kinase-Dependent Signaling Pathway. Front. Immunol. 2018, 9, 1-15. [CrossRef] [PubMed]

13. Kuuva, T.; Lantto, R.; Reinikainen, T.; Buchert, J.; Autio, K. Rheological Properties of Laccase-Induced Sugar Beet Pectin Gels. Food Hydrocoll. 2003, 17, 679-684. [CrossRef]

14. Jiménez León, J.; Rascón Chu, A.; López Elías, J.; Sánchez Villegas, A. Effect of Variety and Seedtime on the Productive Potential of Sugar Beet. Biotecnia 2020, 22, 5-10.

15. Geerkens, C.H.; Nagel, A.; Just, K.M.; Miller-Rostek, P.; Kammerer, D.R.; Schweiggert, R.M.; Carle, R. Mango Pectin Quality as Influenced by Cultivar, Ripeness, Peel Particle Size, Blanching, Drying, and Rrradiation. Food Hydrocoll. 2015, 51, 241-251. [CrossRef]

16. Abid, M.; Cheikhrouhou, S.; Renard, C.M.G.C.; Bureau, S.; Cuvelier, G.; Attia, H.; Ayadi, M.A. Characterization of Pectins Extracted from Pomegranate Peel and their Gelling Properties. Food Chem. 2017, 215, 318-325. [CrossRef] 
17. Alvarado-Padilla, J.; Ávila-Casillas, E.; Camarillo-Pulido, M.; Ochoa-Espinoza, X.; Zamarripa-Colmenero, A. Producción de remolacha azucarera en el valle de Mexicali. INIFAP. 2011. Folleto Técnico No. 19-ISBN: 978-607-425-675-8. Available online: https://www.compucampo.com/tecnicos/produccion-remolachaazucarera-mexicali.pdf (accessed on 15 May 2019).

18. Li, D.Q.; Du, G.M.; Jing, W.W.; Li, J.F.; Yan, J.Y.; Liu, Z.Y. Combined Effects of Independent Variables on Yield and Protein Content of Pectin Extracted from Sugar Beet Pulp by Citric Acid. Carbohydr. Polym. 2015, 129, 108-114. [CrossRef]

19. Yapo, B.M.; Robert, C.; Etienne, I.; Wathelet, B.; Paquot, M. Effect of Extraction Conditions on the Yield, Purity and Surface Properties of Sugar Beet Pulp Pectin Extracts. Food Chem. 2007, 100, 1356-1364. [CrossRef]

20. Carvajal-Millan, E.; Rascón-Chu, A.; Márquez-Escalante, J.A.; Micard, V.; Ponce de León, N.; Gardea, A. Maize Bran Gum: Extraction, Characterization and Functional Properties. Carbohydr. Polym. 2007, 69, 280-285. [CrossRef]

21. Wang, X.; Zhang, L.; Wu, J.; Xu, W.; Wang, X.; Lü, X. Improvement of Simultaneous Determination of Neutral Monosaccharides and Uronic Acids by Gas Chromatography. Food Chem. 2017, 220, 198-207. [CrossRef]

22. Vansteenkiste, E.; Babot, C.; Rouau, X.; Micard, V. Oxidative Gelation of Feruloylated Arabinoxylan as Affected by Protein Influence on Protein Enzymatic Hydrolysis. Food Hydrocoll. 2004, 18, 557-564. [CrossRef]

23. Association of Official Analytical Chemists. Official Methods of Analysis of AOAC International; AOAC International: Arlington, TX, USA, 2002.

24. Bradford, M. A Rapid and Sensitive Method for the Quantitation of Microgram Quantities of Protein Utilizing the Principle of Protein-Dye Binding. Anal. Biochem. 1976, 72, 248-254. [CrossRef]

25. Levigne, S.; Thomas, M.; Ralet, M.-C.; Quemener, B.; Thibault, J.-F. Determination of the Degrees of Methylation and Acetylation of Pectins Using a C18 Column and Internal Standards. Food Hydrocoll. 2002, 16, 547-550. [CrossRef]

26. Urias-Orona, V.; Rascón-Chu, A.; Lizardi-Mendoza, J.; Carvajal-Millán, E.; Gardea, A.A.; Ramírez-Wong, B. A Novel Pectin Material: Extraction, Characterization and Gelling Properties. Int. J. Mol. Sci. 2010, 11, 3686-3695. [CrossRef]

27. Carvajal-Millan, E.; Guigliarelli, B.; Belle, V.; Rouau, X.; Micard, V. Storage Stability of Laccase Induced Arabinoxylan Gels. Carbohydr. Polym. 2005, 59, 181-188. [CrossRef]

28. Guo, X.M.; Zhu, S.M.; Tang, Q.; Yu, S.J. Characterisation of the Turbid Particles in the Extraction of Sugar Beet Pectins. Food Chem. 2014, 162, 99-103. [CrossRef] [PubMed]

29. Rascón-Chu, A.; Martínez-López, A.L.; Carvajal-Millán, E.; Ponce de León-Renova, N.E.; Márquez-Escalante, J.A.; Romo-Chacón, A. Pectin from Low Quality “Golden Delicious” Apples: Composition and Gelling Capability. Food Chem. 2009, 116, 101-103. [CrossRef]

30. Guo, X.; Meng, H.; Zhu, S.; Tang, Q.; Pan, R.; Yu, S. Stepwise Ethanolic Precipitation of Sugar Beet Pectins from the Acidic Extract. Carbohydr. Polym. 2016, 136, 316-321. [CrossRef]

31. Yapo, B.M. Pectin Quantity, Composition and Physicochemical Behaviour as Influenced by the Purification Process. Food Res. Int. 2009, 42, 1197-1202. [CrossRef]

32. Popov, S.V.; Ovodov, Y.S. Polypotency of the Immunomodulatory Effect of Pectins. Biochemistry 2013, 78, 823-835. [CrossRef]

33. Minzanova, S.T.; Mironov, V.F.; Arkhipova, D.M.; Khabibullina, A.V.; Mironova, L.G.; Zakirova, Y.M.; Milyukov, V.A. Biological Activity and Pharmacological Application of Pectic Polysaccharides: A Review. Polymers 2018, 10, 1407. [CrossRef] [PubMed]

34. Wang, H.; Wei, G.; Liu, F.; Banerjee, G.; Joshi, M. Characterization of Two Homogalacturonan Pectins with Immunomodulatory Activity from Green Tea. Int. J. Mol. Sci. 2014, 15, 9963-9978. [CrossRef] [PubMed]

35. Guo, X.; Meng, H.; Zhu, S.; Tang, Q.; Pan, R.; Yu, S. Developing Precipitation Modes for Preventing the Calcium-Oxalate Contamination of Sugar Beet Pectins. Food Chem. 2015, 182, 64-71. [CrossRef] [PubMed]

36. Maxwell, E.G.; Belshaw, N.J.; Waldron, K.W.; Morris, V.J. Pectin-An Emerging New Bioactive Food Polysaccharide. Trends Food Sci. Technol. 2012, 24, 64-73. [CrossRef]

37. Gómez, B.; Gullón, B.; Yáñez, R.; Schols, H.; Alonso, J.L. Prebiotic Potential of Pectins and Pectic Oligosaccharides Derived from Lemon Peel Wastes and Sugar Beet Pulp: A Comparative Evaluation. J. Funct. Foods 2016, 20, 108-121. [CrossRef]

38. Gullón, B.; Gómez, B.; Martínez-Sabajanes, M.; Yáñez, R.; Parajó, J.C.; Alonso, J.L. Pectic Oligosaccharides: Manufacture and Functional Properties. Food Sci. Technol. 2013, 30, 153-161. [CrossRef]

39. Islamova, Z.I.; Ogai, D.K.; Abramenko, O.I.; Lim, A.L.; Abduazimov, B.B.; Malikova, M.K.; Rakhmanberdyeva, R.K.; Khushbaktova, Z.A.; Syrov, V.N. Comparative Assessment of the Prebiotic Activity of Some Pectin Polysaccharides. Pharm. Chem. J. 2017, 51, 288-291. [CrossRef]

40. Leclere, L.; Cutsem, P.; Van Michiels, C. Anti-Cancer Activities of PH- or Heat-Modified Pectin. Front. Pharmacol. 2013, 4, 1-8. [CrossRef]

41. Zhang, T.; Lan, Y.; Zheng, Y.; Liu, F.; Zhao, D.; Mayo, K.H.; Zhou, Y.; Tai, G. Identification of the Bioactive Components from PH-Modified Citrus Pectin and Their Inhibitory Effects on Galectin-3 Function. Food Hydrocoll. 2016, 58, 113-119. [CrossRef]

42. Zhao, J.; Zhang, F.; Liu, X.; Ange, K.; Zhang, A.; Li, Q.; Linhardt, R.J. Isolation of a Lectin Binding Rhamnogalacturonan-I Containing Pectic Polysaccharide from Pumpkin. Carbohydr. Polym. 2017, 163, 330-336. [CrossRef]

43. Funami, T.; Nakauma, M.; Ishihara, S.; Tanaka, R.; Inoue, T.; Phillips, G.O. Structural Modifications of Sugar Beet Pectin and the Relationship of Structure to Functionality. Food Hydrocoll. 2011, 25, 221-229. [CrossRef]

44. Aarabi, A.; Mizani, M.; Honarvar, M.; Faghihian, H.; Gerami, A. Extraction of Ferulic Acid from Sugar Beet Pulp by Alkaline Hydrolysis and Organic Solvent Methods. J. Food Meas. Charact. 2016, 10, 42-47. [CrossRef] 
45. Dobberstein, D.; Bunzel, M. Separation and Detection of Cell Wall-Bound Ferulic Acid Dehydrodimers and Dehydrotrimers in Cereals and Other Plant Materials by Reversed Phase High-Performance Liquid Chromatography with Ultraviolet Detection. J. Agric. Food Chem. 2010, 58, 8927-8935. [CrossRef] [PubMed]

46. Guo, X.; Meng, H.; Zhu, S.; Zhang, T.; Yu, S. Purifying Sugar Beet Pectins from Non-Pectic Components by Means of Metal Precipitation. Food Hydrocoll. 2015, 51, 69-75. [CrossRef]

47. Mulay, S.R.; Kulkarni, O.P.; Rupanagudi, K.V.; Migliorini, A.; Darisipudi, M.; Vilaysane, A.; Muruve, D.; Shi, Y.; Munro, F.; Liapis, H.; et al. Calcium Oxalate Crystals Induce Renal Inflammation by NLRP3-Mediated IL-1 $\beta$ Secretion. J. Clin. Investig. 2013, 123, 236-246. [CrossRef]

48. Ralla, T.; Salminen, H.; Edelmann, M.; Dawid, C.; Hofmann, T.; Weiss, J. Sugar Beet Extract (Beta vulgaris L.) as a New Natural Emulsifier: Emulsion Formation. J. Agric. Food Chem. 2017, 65, 4153-4160. [CrossRef]

49. Chen, H.; Qiu, S.; Liu, Y.; Yin, L. Emulsifying Properties and Functional Compositions of Sugar Beet Pectins Extracted under Different Conditions. J. Dispers. Sci. Technol. 2018, 39, 484-490. [CrossRef]

50. Bai, L.; Huan, S.; Li, Z.; McClements, D.J. Comparison of Emulsifying Properties of Food-Grade Polysaccharides in Oil-in-Water Emulsions: Gum Arabic, Beet Pectin, and Corn Fiber Gum. Food Hydrocoll. 2017, 66, 144-153. [CrossRef]

51. Leroux, J.; Langendorff, V.; Schick, G.; Vaishnav, V.; Mazoyer, J. Emulsion Stabilizing Properties of Pectin. Food Hydrocoll. 2003, 17, 455-462. [CrossRef]

52. Drusch, S. Sugar Beet Pectin: A Novel Emulsifying Wall Component for Microencapsulation of Lipophilic Food Ingredients by Spray-Drying. Food Hydrocoll. 2007, 21, 1223-1228. [CrossRef]

53. Chen, H.M.; Fu, X.; Luo, Z.G. Esterification of Sugar Beet Pectin Using Octenyl Succinic Anhydride and Its Effect as an Emulsion Stabilizer. Food Hydrocoll. 2015, 49, 53-60. [CrossRef]

54. Huang, X.; Li, D.; Wang, L.-J. Effect of Particle Size of Sugar Beet Pulp on the Extraction and Property of Pectin. J. Food Eng. 2018, 218, 44-49. [CrossRef]

55. Karnik, D.; Jung, J.; Hawking, S.; Wicker, L. Sugar Beet Pectin Fractionated Using Isopropanol Differs in Galacturonic Acid, Protein, Ferulic Acid and Surface Hydrophobicity. Food Hydrocoll. 2016, 60, 179-185. [CrossRef]

56. Robert, C.; Emaga, T.H.; Wathelet, B.; Paquot, M. Effect of Variety and Harvest Date on Pectin Extracted from Chicory Roots (Cichorium intybus L.). Food Chem. 2008, 108, 1008-1018. [CrossRef] [PubMed]

57. Sayah, M.Y.; Chabir, R.; Benyahia, H.; Kandri, Y.R.; Chahdi, F.O.; Touzani, H.; Errachidi, F. Yield, Esterification Degree and Molecular Weight Evaluation of Pectins Isolated from Orange and Grapefruit Peels under Different Conditions. PLoS ONE. 2016, 11, 1-16. [CrossRef] [PubMed]

58. Gawkowska, D.; Cybulska, J.; Zdunek, A. Structure-Related Gelling of Pectins and Linking with Other Natural Compounds: A Review. Polymers 2018, 10, 762. [CrossRef]

59. Synytsya, A.; Čopíková, J.; Matějka, P.; Machovič, V. Fourier Transform Raman and Infrared Spectroscopy of Pectins. Carbohydr. Polym. 2003, 54, 97-106. [CrossRef]

60. Fissore, E.N.; Rojas, A.M.; Gerschenson, L.N.; Williams, P.A. Butternut and Beetroot Pectins: Characterization and Functional Properties. Food Hydrocoll. 2013, 31, 172-182. [CrossRef]

61. Zaidel, D.N.A.; Chronakis, I.S.; Meyer, A.S. Enzyme Catalyzed Oxidative Gelation of Sugar Beet Pectin: Kinetics and Rheology. Food Hydrocoll. 2012, 28, 130-140. [CrossRef]

62. Vural, H.; Javidipour, I.; Ozbas, O.O. Effects of Interesterified Vegetable Oils and Sugarbeet Fiber on the Quality of Frankfurters. Meat Sci. 2004, 67, 65-72. [CrossRef]

63. Javidipour, I.; Vural, H.; Özbaş, Ö.Ö.; Tekin, A. Effects of Interesterified Vegetable Oils and Sugar Beet Fibre on the Quality of Turkish-Type Salami. Int. J. Food Sci. Technol. 2005, 40, 177-185. [CrossRef]

64. Berrin, A.; Hüseyin, G.; Furkan, T.C.; Sadettin, T. Effect of Sugar Beet Fiber Concentrations on Rheological Properties of Meat Emulsions and Their Correlation with Texture Profile Analysis. Food Bioprod. Process. 2016, 100, 118-131. [CrossRef]

65. Norsker, M.; Jensen, M.; Adler-Nissen, J. Enzymatic Gelation of Sugar Beet Pectin in Food Products. Food Hydrocoll. 2000, 14, 237-243. [CrossRef] 